\title{
Resenha do Livro: Pensamento Sistêmico: o Novo Paradigma da Ciência
}

\author{
Book Review: System Thinking: the New \\ Paradigm of Science
}

\author{
Raquel Rangel Cesario ${ }^{1 \odot}$
} Manuel Cesario ${ }^{I}$

\section{PALAVRAS-CHAVE}

- Conhecimento.

- Pensamento sistêmico.

- Paradigma.

- Ciência.

- Ciência novo-paradigmática.

- Educação médica.
O livro Pensamento sistêmico: o novo paradigma da ciência exercerá profundas implicações sobre aqueles que desejam compreender as políticas públicas brasileiras para a educação médica, pois tal paradigma estende seus tentáculos para quase todas as áreas do cotidiano, influenciando nossos modos de ser e estar no mundo. Os dois capítulos da parte I apresentam as noções de paradigma e epistemologia, conceitos amplamente utilizados muitas vezes com significados conflitantes, e destacam momentos marcantes no desenvolvimento da concepção de conhecimento científico. Percebem-se a importância do surgimento da ciência para a evolução do mundo e a origem de fenômenos tão presentes e controversos hoje, como a separação entre ciência e filosofia e entre corpo e mente. Os três capitulos da parte II apresentam respectivamente: o delineamento do paradigma tradicional da ciência, as dimensões do paradigma emergente da ciência contemporânea e o pensamento sistêmico como o novo paradigma da ciência. O capítulo 3 apresenta a ciência clássica e tradicional do ponto de vista de três pressupostos fundamentais: simplicidade, estabilidade e objetividade; um quadro de referência com seus próprios termos ajuda o leitor a situar-se em relação a esse paradigma da ciência e ao seu modo de ver o mundo. O capitulo 4 apresenta o paradigma emergente a partir dos pressupostos-espelho daqueles apresentados anteriormente: à simplicidade sobrepõe-se a complexidade; à estabilidade, a instabilidade; e à objetividade, a intersubjetividade. Outro quadro de referência com os termos que se encaixam nos três pressupostos, usados para explicar o novo paradigma, aproxima o leitor de termos mais relevantes para a educação necessária para o século XXI. O capítulo 5 apresenta o cientista novo-paradigmático e defende o pensamento sistêmico como o novo paradigma da ciência. É aqui que o leitor poderá adquirir o argumento que the faltava para se apropriar desse novo paradigma, transformando definitivamente sua postura epistemológica diante das questões da vida e do trabalho. O último capítulo, na parte III, traça as origens das abordagens teóricas dos sistemas e leva o leitor a vagar entre a teoria geral dos sistemas e a cibernética; construtivismo e si-cibernética; a teoria da autopoiese e a biologia do conhecer; a nova teoria geral dos sistemas e a teoria geral dos sistemas autônomos. Embora o paradigma da ciência tradicional ainda seja hegemônico, há evidências de que estamos passando por uma transição paradigmática. A revolução digital mudou a maneira como as pessoas pensam e aprendem; isso exige dos professores e profissionais de saúde treinados no último século uma ampliação do olhar para um objeto que emerge da distinção do(s) observador(es) quando em interação com outros objetos e com o ambiente em que vivem. O livro pode ser um começo para aqueles que se lançam na academia ou uma chegada para os que já iniciaram suas reflexões sobre seus papéis, como professores ou estudantes, nos tempos atuais; deve ser lido e debatido por todos os envolvidos com a formação de profissionais para o século XXI. 


\section{KEY-WORDS}

- Knowledge.

- System thinking.

- Paradigm.

- Science.

- New-paradigm science.

- Medical education.

Recebido em: 9/6/19

Aceito em: 9/9/19

\section{INTRODUÇÃO}

Maria José Esteves de Vasconcellos, psicóloga originária da área da terapia familiar e professora aposentada da Universidade Federal de Minas Gerais (UFMG), brinda os leitores com o excelente livro Pensamento sistêmico: o novo paradigma da ciência, ${ }^{1}$ lançado em 2002 e já em sua 11ª edição. Seis capítulos, bem distribuídos em 269 páginas, exercerão profundas implicações naqueles que desejam compreender os princípios subjacentes às políticas públicas brasileiras para a educação médica.

Se você é um acadêmico pragmático, que não se atém a refletir sobre filosofia e ciência, ao ler esse livro perceberá
ABSTRACT

The book "System Thinking: The New Paradigm of Science" will have profound implications for those who wish to understand Brazilian public policies for Medical Education, since such a paradigm extends its tentacles into almost every area of everyday life, influencing our ways of being in the world. The two chapters of Part I present the notions of Paradigm and Epistemology, widely used concepts and often with conflicting meanings and highlight outstanding moments in the development of the conception of scientific knowledge. The importance of the emergence of science for the world evolution and the origin of phenomena as present and controversial today as the separation between science and philosophy and between body and mind can be perceived. The three chapters of Part II present, respectively: the outline of the traditional paradigm of science; the dimensions of the emerging paradigm of contemporary science; and System Thinking as the new paradigm of science. Chapter 3 presents classical and traditional science from the perspective of three fundamental assumptions: simplicity, stability and objectivity; and a reference framework with its own terms helps the readers to situate themselves in relation to this science paradigm and their way to see the world. Chapter 4 presents the emerging paradigm from the mirror-assumptions of those presented earlier: complexity overlaps simplicity; instability, the stability; and intersubjectivity, the objectivity. Another reference framework with the terms that fit the three assumptions, used to explain the new paradigm, brings the readers closer to terms that are more relevant to the education needed for the $21^{\text {st }}$ Century. Chapter 5 presents the new-paradigmatic scientist and defends System Thinking as the new paradigm of science. It is here that readers can acquire the argument they lacked to be able to appropriate this new paradigm, definitively transforming their epistemological posture in the face of life and work questions. A final chapter in Part III outlines the origins of theoretical approaches to systems and leads the reader to wander between the General Theory of Systems and Cybernetics; Constructivism and Si-Cybernetics; the Theory of Autopoiesis and the Biology of Knowing; the New General Theory of Systems and the General Theory of Autonomous Systems. Although the paradigm of traditional science is still hegemonic, there is evidence that we are experiencing a paradigm shift. The digital revolution has changed the way people think and learn; this requires of teachers and health professionals trained in the last century a widening of their gaze towards an object that emerges from the distinction of the observer(s), when interacting with other objects and with the environment where they live. This book may be a start for those who wish to enter academia, or it may be an advent for those who have started their reflections on their roles, as teachers or students, at the present time; it should be read and discussed by all those involved in the training of professionals for the $21^{\text {st }}$ Century. 
ma da ciência, defendida pela autora de forma didática, além de bem embasada histórica e teoricamente. No início do livro, Maria José Esteves de Vasconcellos conta de forma muito fluida a própria história profissional e a aproximação dela ao pensamento sistêmico, e, simultaneamente, apresenta alguns dos autores que embasarão a sua proposta.

A parte I - "Rastreando as origens do conhecimento científico" -, apresenta, em dois capítulos basilares, as noções de paradigma e epistemologia.

No primeiro capítulo, esses dois conceitos amplamente utilizados, com significados muitas vezes conflitantes, são objeto de um posicionamento claro da autora sobre os fundamentos e sentidos que serão considerados por ela no percurso do livro.

O segundo capítulo destaca momentos marcantes no desenvolvimento da concepção de conhecimento científico. Consideramos esse capítulo imprescindível, na medida em que conhecer a historicidade do desenvolvimento da ciência permite ao leitor tomar consciência das origens dos fenômenos vivenciados em vida e das crenças que determinam suas convicções e seus posicionamentos profissionais e até mesmo pessoais. Percebe-se aqui não somente a importância do surgimento da ciência para a evolução do mundo, mas também a origem de fenômenos tão presentes e controversos atualmente, como a separação entre ciência e filosofia e entre corpo e mente.

A parte II - "Acompanhando as transformações do paradigma da ciência" - desenvolve-se em três capítulos que apresentam respectivamente: o delineamento do paradigma tradicional da ciência, as dimensões do paradigma emergente da ciência contemporânea e o pensamento sistêmico como o novo paradigma da ciência - a cereja do bolo confeitado por Maria José.

Em nota de rodapé, a autora concede ao leitor que julga conhecer bem o paradigma da ciência tradicional a opção de pular o capítulo 3 e ir direto ao 4 . Recomendamos o capítulo 3 mesmo aos mais experientes, uma vez que, desde Descartes, muitos cientistas passaram a fazer ciência, deixando de pensar a ciência; sua leitura fácil apresenta a ciência clássica, ou tradicional, sob o ponto de vista de três pressupostos fundamentais: a simplicidade, a estabilidade e a objetividade. Um quadro de referência de termos próprios da ciência tradicional (previsibilidade, neutralidade, classificação, impessoalidade, racionalidade, multidisciplinaridade, relações causais lineares, atitude "ou-ou", leis gerais, certeza etc.) ajudará o leitor a se situar em relação a esse paradigma de ciência e ao seu modo de ver o mundo.

O capítulo 4 apresenta o paradigma emergente a partir de pressupostos-espelho daqueles apresentados anteriormente: à simplicidade sobrepõe-se a complexidade; à estabilidade, a instabilidade; e à objetividade, a intersubjetividade. O texto, de leitura não tão fácil como o anterior para os não iniciados na física, desenrola-se também com o auxílio de um quadro de referência de termos que se encaixam nos três pressupostos utilizados para explicar o novo paradigma. Aqui o leitor poderá se aproximar de termos (como transdisciplinaridade, desordem, crise, espaços consensuais, conexões, contextualizações, múltiplas verdades, princípio dialógico, foco nas relações, redes de redes, entre outros) caros à educação necessária ao século XXI.

O capítulo 5, apresentando o cientista novo-paradigmático, defende por que a autora entende o pensamento sistêmico como o novo paradigma da ciência. Aqui o leitor que está vivendo a transição de paradigma ou que já fez a ultrapassagem, mas ainda se sente diferente da maioria, às vezes com dificuldade em perceber-se aceito pelos pares, às vezes com culpa por compreender o mundo e portar-se de forma complexa e intersubjetiva, poderá adquirir o argumento que lhe faltava para se apropriar desse novo paradigma, transformando definitivamente sua postura epistemológica diante das questões da vida e do trabalho, pois são indissociáveis.

Finalmente, a parte III - “Um adendo necessário: teorias de sistemas" - presenteia o leitor interessado em se aprofundar nesse estudo com um último capítulo, que rastreia as origens das abordagens teóricas dos sistemas; a autora leva o leitor a passear entre a teoria geral dos sistemas e a cibernética, oriundas do paradigma tradicional, e seus equivalentes mais recentes, como o construtivismo e a si-cibernética, a teoria da autopoiese, a biologia do conhecer, a nova teoria geral dos sistemas e a teoria geral dos sistemas autônomos.

Embora o paradigma da ciência tradicional ainda seja hegemônico em nossa sociedade ocidental e capitalista, várias são as evidências de que vivemos um momento de transição paradigmática. As crises que vivenciamos atualmente, desde políticas, no cotidiano da nossa vida pessoal, até aquelas específicas da educação médica, como a dificuldade em avaliar os estudantes e a epidemia de transtornos mentais entre estudantes e profissionais, têm sua origem na convivência e no embate entre grupos, cada vez maiores, que veem o mundo sob lentes diferentes da maioria, sem essa noção no plano consciente. A revolução digital inaugurou uma nova era histórica e mudou a forma como as pessoas pensam e aprendem; isso exige de nós, professores e profissionais de saúde formados no século passado, uma abertura para a mudança, deixando de lado nossas atitudes neutras, objetivas, fragmentadoras, reducionistas e com foco no objeto, para a ampliação do olhar em direção a um objeto que emerge da distinção do(s) observador(es), 
quando em interação com outros objetos e com o meio em que vivem.

O livro Pensamento sistêmico pode ser o pontapé inicial para os que se lançam na academia e representar a linha de chegada para os que já iniciaram suas reflexões sobre seus papéis, de professor ou de estudante, nos tempos atuais. Ele deve ser lido e debatido por todos aqueles que se comprometem com a formação de profissionais para o século XXI.

\section{REFERÊNCIA}

1. Esteves de Vasconcellos MJ. Pensamento sistêmico: o novo paradigma da ciência. 10. ed. Campinas: Papirus, 2013. $269 \mathrm{p}$.

\section{CONTRIBUIÇÃO DOS AUTORES}

Raquel Rangel Cesario idealizou, debateu e redigiu o artigo; Manuel Cesario debateu, redigiu e revisou o artigo.

\section{CONFLITO DE INTERESSES}

Nenhum dos autores apresenta conflito de interesses.

\section{ENDEREÇO PARA CORRESPONDÊNCIA}

Rua do Jatobá, 909 - Parque do Mirante - Franca - SP

14.410-354 - Brasil 